\title{
Folkelig Forskning?
}

\section{Verner Mфller}

\begin{abstract}
Anmeldelse af: Henning Eichberg \& Claus Bøje Idræetspsykologien mellem krop og kultur DGI Forskning 1997, 68 s.
\end{abstract}

Lad det være sagt med det samme, jeg nærer stor respekt for Gerlev Idratsforsk, der siden grundlæggelsen i 1970'erne har været en dynamo i dansk idrætsforskning, og haft stor betydning som inspirator og åndelig fødselshjælper i forbindelse med initieringen af den universitære forskning, der nu foregår i København og Odense. Efterhånden som disse miljøer er vokset til, er Idrcetsforsks dominans ganske vist for aftagende, men den numerisk lille forskningsenhed har hidtil været $\mathrm{i}$ stand til at holde en imponerende høj publikationsfrekvens, som i omfang og kvalitet ikke har ladet universiteternes idrætsforskningsmiljøer noget efter.

Dog, det første, der springer i øjnene under læsningen, er, at Idræetpsykologien mellem krop og kultur (herefter forkortet IP) er blottet for referencer og henvisninger til den anvendte litteratur. Det er en helt ny akademisk standard, hvis ikke det er genoptagelse af en meget gammel. Under alle omstændigheder er det en uheldig praksis, og det af to grunde. For det første fordi skriftet flere gange i læsningens løb formår at vække læserens nysgerrighed efter at læse videre i de retninger, som skriftet peger. For det andet fordi det ganske enkelt og helt unødvendigt - forekommer uhæderligt, ikke mindst i betragtning af hvor nært der sine steder gås på baggrundsmaterialet.
Man tematiserer »tavs viden $«$ og »mesterlære«, og selvom man deler forsideillustration med Eigil Jespersens Mesterlaere fra 1993, forbigår man i tavshed, at han som den første herhjemme har arbejdet henimod en folkelig idrætspsykologi (for øvrigt også for DGI, mens han var på Gerlev).

Man tager fat på en folkelig fornøjelse som Fagenes Fest og citerer en artikel i Socialdemokraten om tovtrækning fra 1938. Hermed prætenderer forfatterne, at de selv har været i gang med at læse mikrofilm, men griber man til Idrcetshistorisk Årbog 1991 vil man finde præcis det samme citat i Jørn Hansens artikel »Fagenes Fest«, der utvivlsomt er det egentlige forlæg... Og det er ikke de eneste steder, man savner erlæggelse af skyldig mønt.

Man noterer sig, at ingen af de danske idrætsforskere, som påviseligt har befrugtet skriftet, er nævnt, og man spekulerer over grunden, da der synligvis ikke er tale om en konsekvent og tilstræbt uformel og populær fremstilling. Det skorter således ikke på henvisninger til koryfæer som filosoffen Polanyi, kulturhistorikeren Huizinga, psykologen Erikson og teologen Buber. Skønt der heller ikke gives præcise henvisninger til disse, krediteres de dog i brødteksten for deres inspiration til sagen. Deres indsatser overtager forfatterne altså ikke uden videre og gør til deres egne. 
Hvis denne lemfældighed skal være et udtryk for folkelig (idræts)forskning så bevares. Men jeg gætter på, at noget andet er på spil, nemlig en ulyksalig fornemmelse af pres for at være unik og enestående, som følge af den udsatte position man har, når bevillingshorisonten ikke er længere end fra år til år, og man ved, at fjender lurer og 'lobbier'.

Under sådanne vilkår er det psykologisk forståeligt, hvis man søger at tækkes sine alliancepartnere, og her har DGI længe været vigtig. DGI er på sin side interesset $\mathrm{i}$ at få argumenter på hånden til legitimering af deres eksistens. De skyder derfor villigt penge i forskningsprojekter med forventning om, at de intellektuelle kraftkarle på Gerlev vil kunne bidrage hertil. Og selvfølgelig skal man være skruet sammen på en helt særlig måde for ikke at indse, at det er mere fordelagtigt at slikke end bide, den hånd man fodres af. Om det nu er motivet, eller det er forfejlet gisning, så kan det konstateres, at velviljen overfor DGI ofte kommer til udtryk i IP, men desværre også på tværs af arbejdet.

I hvert fald virker det ikke synderligt overbevisende, når der f.eks. skrives: »Idrætten i almindelighed og den folkelige idræt i særdeleshed har dybe socialpsykologiske dimensioner.« (IP s. 12). Hvad siges i grunden, ud over et eller andet venligt, om det folkelige som DGIerne, der bruger folkelighedsbegrebet som mantra, givetvis falder for? Før jeg fortaber mig i detaljer, skylder jeg imidlertid at præsentere skriftets ærinde og skelet.

IP kan næppe opfattes som en egentlig idrætspsykologi. Det er først og fremmest en kritik af den herskende idrætspsykologis begrænsninger og en udmærket markering af, at idrætten omfatter mere, end hvad præstationspsykologien og sundhedspsykologien beskæftiger sig med. Skriftet er fremdeles et forsøg på at kridte banen op for en tredje idrætspsykologi, hvor trialektikmodellen endnu engang udgør skelettet.

At forfatterne (især Eichberg) til stadighed vender tilbage til denne model, kan friste mindre ånder - præget af tidens bestandige stræben efter overfladisk originalitet og nytænkning - til at angribe dem for at være gået åndeligt i frø. Men det er i grunden modigt igen og igen at gennemspille det samme tema i nye variationer. For herved træder modellens konturer stadig tydeligere frem, og det bliver mere og mere åbenbart, hvad der er modellens styrke og svaghed. I kondensat kan det for $\varnothing v$ vrigt siges at være et og det samme, for modellens fortjeneste er primært at påpege, at idræt er andet og mere, end der kan begribes dialektisk. Til gengæld er den ude af stand til at indfange dette mere.

Det tredje (omfattende kropserfaringen, det ekspressive og vel også 'det folkelige') kompletterer ikke den ufuldstændige forståelse af idrætten, som den tager sig ud udspændt dialektisk. Tværtimod bevirker den en forståelse af idrætten som et uigennemskueligt, massivt konglomerat bestående af uendeligt mange elementer. Men i det omfang der insisteres på det tredje som et særligt idrætsligt reservat og ikke som et element $i$ al idræt... sammen med det fjerde, femte, sjette osv, hvorfor det måske mere rigtigt skulle kaldes en facet, tårner problemerne sig op. Og det er desværre men på den anden side ikke overraskende sådan skriftet tematiserer det tredje.

I sine kreative og kritiske momenter, hvor skriftets øjensynligt kultur- eller idrætspolitiske hensigter trænges tilbage af nærværende og engageret saglighed, er det præcis og inspirerende læsning. F.eks. er præsentationen af idrættens firklang sammensætningen af styrke, smidighed, hurtighed og udholdenhed, set i relation til 
de fire elementer jord, vand, ild og luft glimrende og kunne have fortjent at udfoldes yderligere. Fortræffelig er også afsnittene om navnes (identitetsmæssige) betydning - at disse overvejelser bærer præg af at være appliceret på idrætten ad hoc, kan man så bare springe op og falde ned på.

Ligeledes manifesteres nosser bag brunsten, når der stejles over ældreidrætten; både $i$ den sportive variant som eksemplificeres ved Masters Games, der ligesom handicapOL er en udstilling af forfaldet og de uformåendes formåen, og i det infantiliserende og tendentielt nedværdigende 1980'er-projekt ved Odense Universitet: »Ælldre i bevægelse«. På samme vis vises der et godt blik for kunstighed i de kortfattede, men alligevel nuanceret kritiske indvendinger mod »mesterlæren « og »tavs viden «. I det hele taget sættes der hårdt ind mod det søgte - men det udmønter sig ikke i en mere idrætssensitiv analyse. Tværtimod springer en tilsvarende kunstighed i øjnene, idet skriftet ivrer efter at fremstille nødvendigheden af en tredje psykologi.

Til illustration kan vi atter vende tilbage til den folkelige idræt som i særdeleshed skulle have $\gg$ dybe socialpsykologiske dimensioner «. Selvfølgelig efterlader forfatterne os ikke på herrens mark. De uddyber: »Når folk leger, danner de sociale sammenhænge og mønstre; der skabes et »vi«. Gennem bevægelserne og strategierne træder kollektive identiteter i aktion og i udveksling - også i konkurrence - med hinanden. »Vi « leger sammen, eller $» v i \ll$ vinder eller taber. Især idrættens såkaldte folkelighed har grundlæggende at gøre med, hvem »vi« er i denne sammenhæng, og med, hvordan menneskenes kulturelle identitet fremtræder gennem aktiviteten.« (IP s. 12).

Lige indtil folkelighedens særlighed repeteres, kan man nikke genkendende til formuleringerne, der ret præcist rammer en hvilken som helst form for (hold)idræt. Og mistanken, om at folkeligheden simpelt hen skal besværges, mindskes ikke af, at ordet »såkaldte « sniger sig ind. Man smager på formuleringen »idrættens såkaldte folkelighed «, og spekulerer over, hvad den indeholder. Dagbladet Informations beklagelse over det kollektive »vi«s skrumpen i forbindelse med fodboldlandsholdets fiasko ved EM i England, bruges som eksempel, hvilket lægger op til en forståelse af professionel eliteidræt som folkelig. Det passer vældig godt med den morsomme definition på folkelig idræt som en unavngiven svensk idrætssociolog citeres for: »Folkelig idræt er når der begyndes med sang.«(IP s. 18), hvor man straks kommer i tanker om »Der er et yndigt land « som optakt til landskampe. Men det er ikke desto mindre den side af idrætten, som IP mestendels skriver op imod.

Ingen steder giver skriftet en bedre definition af folkelighedsbegrebet end svenskerens, men om modbilledet til Masters Games og ældreidrætten, som forfatterne må til østen for at finde (eksemplet er trancedansen i forbindelse med shamanindvielse) hedder det: »Denne scene fra Indonesien ligger langt væk fra den danske kultur - men den virker alligevel »folkelig «, måske endda mere folkelig end de to andre scener.« (IP s 51)... Skønt bestemt ikke alle kan træde dansen, og det næppe er leg for de dansende osv. Heroverfor må anmelderen melde pas, velvidende at denne melding meget vel kan have sin grund $i$, at han i grunden aldrig har forstået folkelighedsbegrebet, som det har etableret sig i idrætsdebatten. En ting har han dog forstået, og det er, at det bruges som våben mod præstationsidrætten (når den tages alvorligt og udøves på højt niveau). Sådan bruges det også i bemeldte sammenhæng, 
hvor forestillingen om denne idræts skurkagtighed gentages så ofte, at det fremkalder mistanke om, at ærindet går forud for analysen.

Som sagerne fremstilles er præstationsidrætten nødvendig som fjendebillede for at indløse ærindet analytisk. Uden, ville forestillingen om idrætten som en enhed af mangfoldige muligheder nemlig blive påtrængende, trialektikmodellen ville have udspillet sin rolle, og den usædvanlige danske idrætsorganisationsstruktur ville med et blive uselvfølgelig. Så pinedød må fjendebilledet bevares, skønt forfatternes nuanceringer tyder på, at de ikke er så kyklopiske i deres syn på sagen, som den synes at fordre, og det giver selvsagt problemer.

Eksempelvis gives der en god beskrivelse af, hvilke tidløse kvaliteter vi finder i præstationssportens, nemlig: kampen, legen, dansen og fordybelsen. Her har vi jo idrættens substans beskrevet og dermed grundlaget for en forståelse af idrætten som en enhed af mangfoldige muligheder.

Men hævdes det så: »Præstationssporten undertrykker eller forvrænger ganske vist $i$ varierende omfang disse kvaliteter, men der er i realiteten intet, der forhindrer et folkeligt foreningsarbejde $i$ at udvikle en idræt, som i sine bedste $\varnothing j$ jeblikke - uanset præstationsniveau - arbejder med kampen, legen, dansen og fordybelsen. Ikke som konkrete aktiviteter i sig selv vel at mærke, men som dimensioner eller kvaliteter i aktiviteternes indhold og udformning.«(IP s. 30).

Man kan selvfølgelig vælge at tro hvad der står, men der er overladt en god portion fortolkningsarbejde til den 'ateistiske' læser, der ikke umiddelbart tager det skrevne ord for gode varer. Hvordan undertrykkes og forvrænges kampen og de øvrige elementer i sporten? Udfoldes ikke allerede bemeldte kvaliteter i præstationssportens »bedste øjeblikke «? Hvad er det da, der helt præcist skal gøres anderledes i det folkelige foreningsarbejdes arbejde med f.eks. præstationsidræt? Og hvad er overhovedet de substantielle indvendinger mod den traditionelle præstationsidræt?

De kritiske indvendinger IP opviser er ikke overbevisende. Der er ganske vist drøn på, når eliteidrætten karakteriseres som: »Brutal og destruktiv fremfærd, invaliderende specialtræning, doping, korruption, autoritære ledelsesformer, kommerciel udnyttelse og selvhævdende vinderattituder « (IP s. 30), men at bruge det som argument imod eliteidrætsdyrkelse er ikke anderledes end at argumentere mod bilkørsel med henvisning til at nogen kører for stærkt. I grunden synes beskrivelsen ikke andet end et udslag af ideosynkratisk proportionsforvrængning. At præstationsidrætten ikke er så let at få afvaloriseret viser sig, da forfatterne senere kritiserer store dele af dagens idræt for at overse betydningen af idrættens ovennævnte firklang. »Det gælder mange af de traditionelle idrætsgrene, som i deres specialiseringsfilosofi nøjes med det »relevante«« (IP s. 33). Men tager man f.eks. de store boldspil i øjesyn, er det oplagt, at man netop her aldrig vil nå eliteniveau, hvis ikke man udvikler såvel smidighed, hurtighed, udholdenhed som styrke.

Ærindet synes i det hele taget af føre forfatterne bort fra en basal forståelse af idrættens væsen. Et angreb formuleres f.eks. således: »Præstationssporten bygger på aktiviteter, som stort set alle rummer muligheder for, at det legende kan komme til udfoldelse. Der er ingen grund til at afvise denne rigdom af aktiviteter, blot fordi sportens praksis reducerer eller negligerer relevansen af en legende indfaldsvinkel.« (IP. s. 31). Her siges i al enkelhed, at leg er mulig i sport, men i praksis er det det 
næsten ikke. Hvad forfatterne, i deres distancerede betragtning overser, er, at sport fundamentalt er leg, om end alvorlig leg. Den leg forfatterne finder har så ringe vilkår i sporten, er ret beset legen i legen. Den findes også, men denne niveau to leg skal selvfølgelig være effektiv for niveau et, hvis ikke den skal henvises til en anden bane. Det er imidlertid et forhold, som ikke er særligt for sporten, men gælder en hvilken som helst form for organiseret leg.

Denne ikke-forståelse for sportens væsen synes paradoksalt at have nødvendighedskarakter i IP, men resultatet er, at kritikken bliver blodfattig, og de særlige folkelige potentialer $\mathrm{i}$ en anderledes idræt tegner sig som et tamt og ukonsolideret postulat.

Som et sidste eksempel på miseren kan IPs opgør med eliteidrættens fascinationskraft tjene. Forfatterne kan selvfølgelig ikke se bort fra, at der findes »bedste øjeblikke« i eliteidrætten, men da ærindet er at promovere det folkelige, må det (bort)forklares som rent undtagelsesvist: »I dansen findes på den ene side drømmen om den ubesværede bevægelse, den fuldkomne timing og den ekstatiske selvforglemmelse [...]. Når sportens fodboldpublikum henrykkes af brødrene Laudrup, er det, fordi de har udstråling i kraft af deres evne og vilje til at skabe de overrumplende og vanskelige momenter. De udstiller, på et ofte sublimt artistisk niveau, billeder på menneskets fantastiske udtryksrepertoire. Den æstetisk-ekspressive dimension kan gan- ske vist i præstationssporten kun accepteres, såfremt den er effektiv; og den kalder - hvis den er effektiv - øjeblikkeligt på modtræk fra modstanderne; tæt markering, personlig opdækning, intimiderende spillestil etc. Men den udtrykker en drøm, som også - selv når den har svært ved at komme til udfoldelse - forbindes med sporten: Drømmen om at opleve den ubesværede demonstration af menneskekroppens skønhed «. (IP s. 31).

Citatet viser forfatterne stående uden for en idrætslig forståelseshorisont. Betragtningen er ikke stort anderledes, end når det foreslås at give hver spiller en bold, så de ikke alle behøver løbe efter den samme. Det lades fuldstændig ude af betragtning, at det netop er på grund af, at de overrumplende afleveringer og de besnærende driblinger er uhyre vanskelige, men yderst effektive at beherske, at vi som tilskuere falder i svime over dem. Derfor forstærker det også kun de bedste øjeblikke, at modstanderne yder deres yderste for at forhindre disse tryllerier i at komme til udfoldelse. Den vekslen mellem magt og afmagt, det beherskede og beherskende, som her er på spil, er behæftet med (idræts)psykologiske implikationer, som det var værd at udforske, og selvom genstandsfeltet er præstationsidrætten, viser de netop en vej ud over en snæver præstationspsykologi. Men denne vej overses - vel sagtens fordi sportskritikken blinder. 